\title{
DAVID MASSON, BELLES LETTRES, AND A VICTORIAN THEORY OF THE NOVEL
}

\author{
By Jack M. Downs
}

IT MIGHT SEEM BOLD, or even presumptuous, to assert that there is a clearly identifiable unified theory of the novel present in any aspect of Victorian literary culture. As John C. Olmsted rightly observes, assessing the presence of any specific and consistent critical stance in Victorian criticism is a difficult task; thus, any attempt to evaluate Victorian criticism of the novel is problematic. Victorian periodical criticism is

inconsistent, [and] most of it is deservedly forgotten.... The reader [of early Victorian novel criticism] finds he must take into account the prejudices of individual reviewers, the political affiliation of the periodical in which a review appears and, all too often in the $1830 \mathrm{~s}$, the ties that journals and reviewers had with publishing houses. (Olmsted xiii-xiv)

Another problem in assessing Victorian novel criticism lies in the aggressively non-theoretical stance of many Victorian critics. Edwin Eigner and George Worth characterize Victorian criticism of the novel as "written by highly intelligent reviewers and essayists . . . [most of whom] rather prided themselves on the non-theoretical character of their intellects" (1). The absence of theory - perceived or in actuality - in Victorian criticism makes the task of identifying common theoretical concerns and systematic approaches a difficult proposition.

Yet there is a common theoretical component in much Victorian criticism, and these theoretical leanings are often explicitly beholden to belles lettres rhetorical principles carried over from the eighteenth-century. For example, in an 1840 review of The Dowager published in the Athenaeum, Catherine Gore begins by pointing out the presence of "canons of criticism" which include "the prevailing state of education, the current acquaintance with rhetoric, with the principles of the sublime and beautiful, or, in one word, with the science and the art of composition" (899). While such a statement appears unremarkable at first glance, Gore's references to rhetoric, to sublimity and beauty, and to the art of composition are perhaps best understood as clear examples of the presence of a belles lettres-influenced critical stance within Victorian critical discourse.

But what, exactly, constituted a belles lettres-influenced critical stance? Answering such a question necessitates marking the delineation between eighteenth-century belles lettres rhetorical theory and subsequent nineteenth-century belles lettres-inflected literary criticism: while the two traditions sometimes operated side-by-side, they often maintained 
independent concerns. Eighteenth-century belles lettres rhetorical theory, typified by the work of University of Edinburgh professor Hugh Blair, offered a revision to the traditional purview of rhetoric, infusing classical rhetoric with a wide range of influences, including aesthetic principles borrowed from seventeenth-century French criticism that emphasize the operation of taste, judgment, and style within discourse. Additionally, belles lettres rhetoric developed the analytic rather than generative functions of rhetorical theory. For Blair and other proponents of belles lettres rhetorical principles, this approach to rhetoric naturally encompassed the study of literature as part of a larger project of understanding the nature of taste, style, and judgment within any mode of discourse.

The most paradigmatic manifestation of eighteenth-century belles lettres rhetorical theory is found in Blair's widely read and exceptionally influential Lectures on Rhetoric and Belles Lettres. Blair's lectures, which he delivered at the University of Edinburgh with few revisions from 1759 until his retirement in 1783, present a highly detailed and systematic application of belles lettres principles to the analysis of a wide range of genres: Blair examines historical writing (including biography and memoir), philosophy, poetry (pastoral, didactic, dramatic, and epic), tragedy, fiction, and comedy. Yet the bulk of Blair's lectures are focused on concepts more commonly associated with oratory and traditional rhetorical theory, and perhaps only one third of the lectures deal with what might be classified as literary criticism. Blair's lectures develop a rhetorically sensitive theory of style, taste, and judgment, and his analysis of any text is in the service of that larger aim. While the lectures are formal and systematic, Blair is not specifically interested in developing a comprehensive theory of literature or literary history.

The influence of Blair's Lectures on nineteenth-century British literary culture is impossible to deny, and just as difficult to make concrete. Blair began teaching rhetoric at the University of Edinburgh in $1759^{1}$ and published the Lectures in 1783 in order to counter the large volume of unauthorized versions of his lectures that began appearing during the latter part of his tenure at the University of Edinburgh (Ferreira-Buckley and Halloran xvi). Tracking the publication and distribution of texts during the eighteenth and nineteenth century is a difficult task, and in the case of a text as popular as Blair's Lectures, which was widely anthologized in textbooks and collections of "extracts," establishing exact numbers for publication or readership is almost impossible. But the significance of the lectures is hard to overestimate. Miller asserts that upon their publication in 1783, "Blair's Lectures on Rhetoric and Belles Lettres swept the emerging field [of English studies], passing through over one hundred and ten editions" (2). Golden and Corbett are more specific: "The Lectures had a phenomenal sale . . during the first century after publication . . . Robert M. Schmitz list[s] twenty-six editions in Great Britain . . . and fifty-two abridged editions" (25). In their 2005 introduction to Blair's Lectures, Ferreira-Buckley and Halloran argue that Blair's works were among the most influential English studies texts of the latter eighteenth century and the first half of the nineteenth (xv-xxiii). They also observe that Blair's influence extended beyond the classroom to informal study in book groups, home study, and mechanics institutes. Ferriera-Buckley and Halloran argue that Blair's influence penetrated every strata of literate British culture. Bizzell and Herzberg in turn describe Blair as "the Quintilian of his time, combining in his rhetoric a theory that met with nearly universal approval and a pedagogy that won nearly universal application" (947).

The question of Blair's significance, then, turns on the ability to identify his influence, and as St. Clair observes in The Reading Nation in the Romantic Period, "[h]ow to assess influence 
is among the most difficult of all the methodological challenges that historians face in attempting to understand the diffusionary rise and fall of ideas" (268). Despite this difficulty, St. Clair asserts that Blair's Lectures can be taken, with Burke's Philosophical Enquiry into the Sublime and Beautiful, as the most widely read and accepted aesthetic statements of the eighteenth century $(270,581,583)$. But St. Clair's exhaustive appendices reveal the comparative distribution of Blair's Lectures versus Burke's Enquiry was hardly equal. Between 1783 and 1825, 20,500 copies of Blair's Lectures were printed. By comparison, only 4,000 copies of Burke's Enquiry are known to have been published between 1757 and $1807 .^{2}$ No matter how influence is calculated, what is certain is that Blair's Lectures, in extracts and anthologies, were enthusiastically read, consulted, and recommended across a broad spectrum of the reading public throughout the romantic period and beyond.

Unlike the eighteenth-century belles lettres rhetorical theories that preceded it, belles lettres-influenced literary criticism that emerged in the nineteenth century rarely produced the sort of formal and systematic treatments typified in rhetorical works such as Blair's Lectures. Instead, and in keeping with the Victorian cultural aversion to formal theory, the role and nature of nineteenth-century belles lettres-inflected literary criticism might be best described as a variety of literary discourse characterized by an informal and widely-varying application of aesthetic principles extracted from eighteenth-century belles lettres rhetorical theory. Due to the long-standing influence and popularity of belles lettres rhetorical treatises such as Blair's, these aesthetic principles were broadly diffused throughout the horizon of expectation for Victorian literary discourse and only rarely was any attempt made to articulate a systematic belles lettres-influenced critical approach. And although individual eighteenth-century treatments of belles lettres rhetorical theory were often highly formal and systematic, the full spectrum of belles lettres rhetorical theory incorporated a dizzying range of influences, including classical rhetoric, common sense philosophy, early expressions of cognitive psychology, seventeenth-century French aesthetic theory, and Enlightenment empiricism. Such a panoply of influences certainly complicates attempts to identify any of the central concerns of belles lettres rhetorical theory, which were later appropriated by belles lettres-influenced literary criticism of the nineteenth century. Yet it is possible - and indeed, helpful - to identify three major inter-related threads within eighteenth-century belles lettres rhetorical theory which were crucial concepts within nineteenth-century literary criticism. These concepts were propriety, taste, and sublimity (Warnick 5).

Briefly, propriety can be seen as a criterion of style, including audience expectations, adherence to genre conventions, and the execution of the artist's moral and ethical intent. Taste, a concept that developed out of eighteenth-century faculty psychology, is a measure of the reader's ability to effectively apply critical concepts (such as propriety) and offer judgments about aesthetic experiences. Sublimity, a rhetorical concept with its roots in ancient Roman rhetorical theory, fused an aesthetic appreciation for the greatness of subject matter with greatness of expression and was, in Barbara Warnick's words, "the pathetic dimension of aesthetic influence" (5). Sublimity was frequently associated with individual genius, in which genius was often understood as an artist's ability to achieve and sustain sublimity. These three concepts were crucial to eighteenth-century belles lettres rhetorical theory, and were also of central importance in the informal development of belles lettresinfluenced literary criticism of the nineteenth century. While these three concepts will later be explored and expanded in some detail, for the moment it should suffice to say that the 
triumvirate of propriety, taste, and sublimity provides a useful heuristic for encapsulating the vast range of belletristic critical concerns present in Victorian critical discourse.

While Gore's assessment of The Dowager is a typical example of belles lettres-influenced periodical criticism of the Victorian era, the periodical press is not the only venue in which a belles lettres-inflected theory of the novel emerged. As Thomas P. Miller, Robert Crawford, and Linda Ferriera-Buckley have demonstrated, when English literature began to appear in Scottish universities in the latter half of the eighteenth century and in the new London universities - University College (originally called The London University) and King's College - in the 1820s and 1830s, it appeared as an extension of existing courses in rhetoric. And one concept that clearly emerges from these early university courses in English literature is the importance of eighteenth-century Scottish rhetorical theory and training in the development of English literary studies in the Victorian academy. Applications of this rhetorical training to practical criticism resulted in the development of belles lettresinfluenced critical standards, and the importance of propriety, taste, and sublimity are clearly evident throughout Victorian criticisms of the novel. Ferreira-Buckley in particular draws a fairly straight line from eighteenth-century Scottish rhetoricians - especially Hugh Blair - to the theoretical and critical bases for English literature courses taught at King's College by Thomas Dale (1835-40), and at University College by Dale (1828-30), Alexander Blair (1830-36), Henry Rogers (1836-53), and David Masson (1853-65). ${ }^{3}$ These early professors of English literature were often Scottish-born and educated literati who explicitly incorporated Scottish belles lettres rhetorical principles into the design and execution of their academic work, especially in regard to Blair's widely popular Lectures ${ }^{4}$ and also to a lesser extent the work of fellow Scottish literati, including Henry Home (Lord Kames), Adam Smith, George Campbell, and James Beattie. ${ }^{5}$

Perhaps the most paradigmatic of the pioneering nineteenth-century Scottish professors of English literature is David Masson, the Aberdeen-born and Edinburgh-educated editor of Macmillan's; biographer of Milton, Shakespeare, Carlyle, and Drummond; editor of Thomas de Quincey's work; and prolific contributor to British literary periodicals. And while it might be argued that there were other Victorian literary figures who were at least as influential (if not more so), very few can claim to match the range of Masson's influence as periodical contributor, editor, literary biographer and historian, public critic, contributor to the Encyclopedia Britannica, and university professor. While currently there is no readily available complete bibliography of Masson's work, his scholarly and critical output was immense: Masson published twenty-six books of biography, history, personal memoirs, and literary criticism and the Dictionary of Literary Biography lists a selected bibliography of Masson's periodical writing that includes over a hundred articles published in Macmillan's, Fraser's, the North British Review, the British Quarterly Review, the Edinburgh Review, and a host of other periodicals. In addition, Masson's work appeared on both sides of the Atlantic: for example, the New York-based Nation published several reviews of Masson's work in the 1860s and 1870s, and Masson's British Novelists and their Styles was published Philadelphia in 1859. Masson, then, was a well-regarded critic and scholar whose production in the periodical press ranks him as one of the most productive critics of the latter half of the nineteenth century.

While Masson's theory of the novel is accessible through his 1859 volume British Novelists and their Styles, a full examination of his critical assessment of the novel, including his courses in Rhetoric and English Literature at the University of Edinburgh, ${ }^{6}$ demonstrates 
the remarkable consistency of his theory of the novel from some of its earliest iterations in the periodical press to the end of his academic career in 1895. Because Masson was one of the most well-connected and influential critics of the mid- to late-nineteenth century, ${ }^{7}$ the choice of Masson as a focal point for understanding a Victorian theory of the novel as developed within the academy is due in large part to the breadth and depth of his influence outside the academy: his six-volume Milton biography, ${ }^{8}$ along with his production as a critic within the periodical press and his role as the first editor of Macmillan's Magazine, establish Masson as a major figure in Victorian literary criticism. Assessing Masson's theorization of the novel within the academy thus provides useful and detailed contextualization for his non-academic work, and fosters, to a limited degree, a sense of the far-reaching influence of eighteenth-century Scottish belles lettres rhetoric within Victorian theorizations of the novel.

\section{Scottish Belles Lettres and a Rhetorical-Historical Theory of English Literature}

MASSON'S THEORY OF THE NOVEL is embedded within his larger general theory of literature, and despite previously stated claims that, in general, Victorian critical projects are decidedly non-theoretical in nature, Masson's criticism possesses a distinctly theoretical vector based on two other foundational disciplines: the previously mentioned belles lettres-influenced literary criticism and literary history. Masson's application of rhetorical principles and concepts is distinctive in its formal and systematic deployment of a modified version of eighteenthcentury Scottish belles lettres rhetorical theory.

Eighteenth-century Scottish belles lettres rhetoric, especially as disseminated in the work of University of Edinburgh professor Hugh Blair, attempted to modify the centuries-old classical rhetorical tradition for a rapidly developing print culture driven by the accelerated spread of literacy during the latter half of the eighteenth century. Though the belles lettres rhetoric of eighteenth-century Scottish universities drew on classical rhetorical theory, it also "subordinate[d] formal divisions, long lists of terms, and rote strategies in favor of a robust psychological approach, natural style, and a firm linguistic . . f foundation" (Engell 218). Further, these revisions to traditional rhetoric were intended "as . . . a complete system of criticism and a guide to improving style and taste" (218). By the mid-eighteenth century, the emerging belles lettres rhetorical movement was sometimes recognized as indistinguishable from literary criticism. St. Andrews University rhetoric professor Robert Watson explicitly states such a claim in 1758 :

By the Rules of Rhetorick are meant Nothing else, but Observations concerning the Particulars which render Discourse excellent \& usefull. It is not proposed to deliver them in the Form of Rules, but in the form of general Criticisms illustrated by Examples from Authors. To what follows then you may give the Name of Rhetorick, or Criticism if you please; if they deserve the one they will deserve the other also. (qtd. in Rhodes 29)

Watson's conflation of rhetoric and criticism is the inevitable outcome of the eighteenthcentury concern for the moral formation of the individual reader. As the literate public expanded to include readers from every rung of the social ladder, the development of a systematized approach for judging and appreciating written discourse was only natural. Poorly formed taste and judgment, especially in younger readers, was seen as dangerous to 
moral formation, and the project of developing a critical system which would emphasize the exercise of proper taste and judgment was taken up by rhetoricians.

Yet even as Watson conflated rhetoric and criticism, the belles lettres-influenced approach to literary criticism was being recognized as distinct from its belles lettres rhetorical foundation. Blair's career and published work provides perhaps the most salient example of this shift. The title of Blair's position at the University of Edinburgh - the Regius Chair of Rhetoric and Belles Lettres - is telling in its separation of belles lettres from rhetoric, and such a separation is evident throughout Blair's widely read Lectures. ${ }^{9}$ In the Lectures, Blair reversed the ancient purpose of rhetorical training: instead of focusing outward on the production of discourse, belles lettres rhetoric increasingly focused on the inward analysis of discourse, especially written discourse including essays, history, poetry, and fiction. Blair makes this shift unmistakably clear early in the Lectures when he defines criticism as "the application of Taste and of good sense to the several fine arts" (121). Blair understood taste to be an inborn faculty common to everyone; however, taste was not present in the same proportion or acuteness in everyone. This natural faculty could also be expanded and cultivated through contact with works of art, literature, and music that were broadly acknowledged to be works of genius.

Blair deeply admired the work of Roman rhetorician Quintilian, and he certainly agreed with Quintilian's belief that a true rhetor was also a moral person. But in response to Quintilian's well-known formulation of the rhetor as a good man speaking well, Blair asserts that his lectures might offer students the prospect of "acquir[ing] principles which will enable them to judge for themselves" concerning literature and art (5). The individual's development of proper taste and judgment thus became a civic obligation: individuals exercising correct judgment could effectively shape a national sense of taste. But Blair and his belles lettres colleagues in the Scottish universities placed a decidedly individualistic emphasis on the power of great art to develop the twin faculties of taste and judgment. In Blair's formulation of belles lettres rhetoric, Quintilian's virtuous Roman citizen-orator speaking well becomes Blair's respectable British gentleman exercising his correctly-formed taste and judgment. The rhetor, in other words, is replaced by the critic.

This is not to say that Blair and the other belles lettres rhetoricians of the eighteenth century ignored oratory, or bypassed the long-standing rhetorical emphases on figures, tropes, and other devices. Indeed, the majority of Blair's Lectures are devoted to such matters. But tropes and figures in the service of generating discourse were subordinated and increasingly applied to the analysis, and not the production, of discourse. The critical and analytical function of rhetorical training steadily took precedence, while the traditional and ancient generative function of rhetorical theory gradually devolved into rote lists, tired formulae, and outdated maxims. The eventual Romantic veneration of sublimity and individual genius - concepts that had firm foundations in rhetorical theory - helped complete the separation of belles lettres-influenced critical discourse from its belles lettres rhetorical foundation.

As we will see, Masson's theory of the novel - and of literature in general - is firmly rooted in the belles lettres-influenced critical tradition which emerged from belles lettres rhetorical theory propounded by eighteenth-century academics such as Blair. The other foundational discipline for Masson's theory, literary history, is in many ways closely intertwined with his rhetorical influences. Belles lettres-inflected critical practices carried over the long-standing rhetorical tradition of utilizing examples of excellence in discourse as a training tool. However, in the belles lettres reformulation of classical rhetoric, great 
examples from the past are not held up as patterns to be imitated, but as standards for comparison in establishing proper taste and judgment. Blair is exceptionally clear about the place of examples in belles lettres-influenced criticism:

The rules of Criticism are not formed by any induction, a priori, as it is called; that is, they are not formed by a train of abstract reasoning, independent of facts and observations. Criticism is an art founded wholly on experience; on the observation of such beauties as have come nearest to the standard which I before established [the application of Taste and of good sense to the several fine arts]; that is, of such beauties as have been found to please mankind most generally. (21)

For Blair, the most prominent and widely read of the Scottish belles lettres rhetoricians, the proper development of taste and judgment is in large part predicated on a correct understanding of literary history. Blair argues that criticism is thus useful to every writer, because "there is no writer but may receive assistance from critical observations upon the beauties and faults of those who have gone before" (21). Thus, literary history is one of the foundational disciplines necessary for forming correct critical judgments within belletristic criticism.

\section{Masson's Theory of the Novel: The Periodical Press}

BEFORE EXAMINING MASSON'S THEORY of the novel as presented in his university courses, it is worthwhile to contextualize those courses through a brief examination of his novel criticism up through the publication of British Novelists and their Styles, Masson's 1859 fulllength work on the history, theory, and nature of the British novel. Masson's vast periodical production precludes an exhaustive study of his periodical criticism; however, through a brief consideration of just two reviews - Masson's 1849 review of Douglas Jerrold's A Man Made of Money, published in the British Quarterly Review, and his 1851 comparative reviews of Dickens's David Copperfield and Thackeray's Pendennis, published in the North British Review - clear rhetorical-historical principles emerge as the cornerstones of Masson's theory of the novel. Masson grounds his theory of the novel on belles lettres-inflected critical concepts of propriety and taste, with genius substituted for sublimity in the belles lettres critical triad. ${ }^{10}$ In Masson's formulation of belles lettres-influenced criticism, a correctly developed understanding of propriety in discourse is necessary for the formation of proper taste and the attendant exercise of correct judgment. Propriety and taste are best developed through contact with widely acclaimed works of genius from throughout literary history. These intertwined belletristic critical concepts permeate Masson's work, and any attempt to make sense of Masson's critical projects hinges on understanding these ideas.

The first of these, propriety, is somewhat complex. The eighteenth-century concept of propriety, infused into belles lettres-influenced criticism of the nineteenth century through the work of Hugh Blair and other Scottish rhetoricians, was developed from the conflation of two intertwined concepts - vraisemblance and bienséance - found in French rhetorical theory of the late seventeenth and early eighteenth centuries. Warnick explains that "[V]raisemblance is a broader and more inclusive concept and arises from the congruence of facts and events in a text. ... In its preoccupation with the manner of expression and the artfulness of portrayal, bienséance is an aesthetic criterion, whereas verisimilitude [vraisemblance] deals with the 'logic' of a work" (40-41). In other words, propriety in discourse is located within the 
collision between a work's internal style, execution, and unity, and the external audience expectations for the work in question.

For Masson, propriety was a question of both aesthetic execution and ethical intent. Neither concept was more important than the other, but when a work emphasized one at the expense of the other, the propriety of the work suffered. For example, in Masson's 1849 review of Jerrold's A Man Made of Money Masson goes to great lengths to defend Jerrold's character and reputation as a public wit. However, in the end Masson criticizes Jerrold's inability to balance ethics with aesthetics: "in Mr. Jerrold, the moralist, the satirist, prevails over the artist. His creations are, in most cases, but vehicles for some feeling or opinion" (199). This is an archetypal belles lettres-inflected critical stance. Glancing back to the eighteenth-century progenitors of belles lettres-influenced criticism, we find that the rhetorical program for developing taste and judgment laid out by Blair and other Scottish belles lettres rhetoricians certainly values the role fiction might play in promoting virtue and condemning vice, but Blair very clearly believes that artistry should never be sacrificed to message. For the belles lettres-influenced critic, great art explores the tension between ethics and aesthetics without ever giving precedence to one or the other. It is in this vein that Masson, while appreciative of Jerrold's character and abilities as a satirist, is very clear in his judgment that Jerrold, by concerning himself with message at the expense of art, fails to achieve true artistic greatness.

Masson begins his review of Jerrold's A Man Made of Money by arguing for the importance of understanding the author's character in developing a correct critical perception of a work. In Jerrold's case, Masson asserts that the author's reputation as a public wit should not undercut the reader's appreciation for his other gifts as a novelist. In particular, Masson highlights the clarity and feeling present in Jerrold's work, concepts which are deeply indebted to his own relationship to a belles lettres-influenced critical heritage (193). Masson's defense of Jerrold is almost entirely founded on appeals to the writer's superior gifts of good sense and right feeling, qualities which Masson laments are frequently obscured by his talents and reputation as a wit and a comic contributor to Punch. Masson argues that wit, while admirable and enjoyable, cannot be the sole criterion of appreciation for any novel, and he points to Dickens as the preeminent example of a novelist whose gift for comedy augments his natural "kindliness of nature" and "keenness of perception" (196).

While Masson's appreciation for Jerrold is clearly evident, Masson does not hesitate to place him a rank lower than Dickens or Thackeray as a novelist, primarily because Jerrold does not successfully endue his characters with the kind of depth and realism expected by Masson. Masson criticizes Jerrold for creating characters of little substance, and who serve a primarily utilitarian place within the context of the novel, but are forgettable once the reader completes the novel (199). This sort of observation clearly echoes the importance of vraisemblance (adherence to realism) and bienséance (propriety of a novel's execution), the twin pillars of propriety in the belles lettres-influenced critical approach.

In Masson's well-known 1851 review and comparison of Dickens's David Copperfield with Thackeray's Pendennis, his belles lettres-inflected critical tendencies are also clearly evident. After describing the thematic similarity between the two bildungsroman novels, Masson begins his review with an examination of each novelist's adherence to propriety through an examination of their style. Masson proposes a fascinating project for the reader: Masson presents selections from both novels and suggests that the properly trained reader should be able to distinguish one author's work from the other's simply through an 
examination of style (59). Like Blair in the eighteenth century, Masson clearly thinks that novel readers should be equipped with a belles lettres-informed critical sense of propriety in discourse which aids in developing correct taste, allowing such readers to draw comparisons and make judgments for themselves. ${ }^{11}$

Masson's assessment of the two varying styles is exact and precise: "Mr. Thackeray is the more terse and idiomatic, and Mr. Dickens the more diffuse and luxuriant writer" (61). In presenting a more thorough description of their stylistic differences and similarities, Masson depends upon belles lettres-inflected critical conventions: he commends both for the clarity of their language, and notes that Thackeray's prose will be more appealing to those who adhere to a preference for an Anglo-Saxon purity in language espoused at least a century earlier in Adam Smith's rhetoric lectures delivered at the University of Glasgow. ${ }^{12}$ While Masson compliments the exceptional propriety and taste of both authors, Dickens is noted for his genius, and for possessing an "instinct . . . for the pure and beautiful" (62). Masson then offers a typical belles lettres rhetorical exercise in comparison: Thackeray is similar to Balzac in keenness of thought, insight, and sagacity. Dickens is criticized for risking his artistic projects by extensively polemicizing and moralizing in his fiction, though Masson allows that Dickens's genius typically tips the balance in favor of his artistry over his moralizing.

\section{Masson's Theory of the Novel: British Novelists and their Styles}

MASSON'S RHETORICAL-HISTORICAL THEORY of the novel receives its most complete, widely published treatment in British Novelists and their Styles. Masson begins by defining the novel in relation to other literary genres. The novel is situated within a taxonomy of imaginative literature; Masson asserts that the novel is a species of poetry, or more specifically, poesy, and is in fact the "prose counterpart to Narrative Poetry" (12). The novel can aspire to true greatness: "the novel, at its highest, is a prose epic" (12). For Masson, the association of the novel with the epic is crucial: linking the novel with the epic provides a framework for historicizing the novel, as well as offering a heuristic for understanding future developments of the genre (12-13). Masson thus structures his examination of the novel within an explicitly historical framework: the novel, he informs us, has passed through the various stages of literary history in the same way as every other literary form; in doing so, Masson crafts his defense of the novel around both a belles lettres-inspired emphasis on the importance of accepted models and the centrality of historically-based comparisons. Masson defends the comparison of "one of our thousand-and-one stories of society in Mayfair, and Homer's old story of the wanderings of Ulysses" by citing German scholar Christian Charles Josiah Bunsen's assertion that only the prose fiction of the previous three centuries that can be regarded as epic is still remembered (13). In the correct context, Masson argues that not only are novels always comparable to epic poetry, but also that such a comparison is a necessary component in understanding the genre:

In short, if we think only of good novels in connection with good narrative poems, throwing equally out of sight what is inferior in both departments, the association of the Novel with the Epic will not seem so much amiss. At all events, in tracing the history of a Novel, there will be some advantage in recollecting the association. The phases through which the Novel has passed will be found to be not unlike those through which Narrative Poetry has passed; and, in any particular country, the Prose 
Fiction of a period will be found to exhibit the characteristics seen also in the contemporary Narrative Poetry. (14-15)

Masson's sustained association of the novel with the epic demonstrates two of the most salient features of his theory of the novel: the importance of historical contextualization and the necessity of rhetorical situatedness.

Masson continues to defend his association of the novel with epic poetry, arriving at the conclusion that one of the primary differences between narrative prose and narrative verse is the suitability of prose for humor and the presentation of everyday life and circumstance (2427). This is a crucial point: Masson's assertions concerning the commonplace and everyday as novelistic subject matter are hardly original; however, Masson's identification of the novel as a genre intrinsically and uniquely suited to the task of providing a realistic representation of everyday life moves beyond a typical invocation of the ordinary as novelistic subject matter. Rather than viewing the commonplace and ordinary as the subject matter most frequently chosen by novelists, Masson implicitly argues the reverse: the selection of prose fiction as a mode of literary discourse necessarily leads to the selection of everyday and ordinary subjects. At times, Masson argues for an almost Bakhtinian sense of the novel's capacious nature, asserting that the novel is better suited to a wide range of possibilities: apart from the intrinsic presentation of everyday life and actions, novels are better at depicting historic narratives (26), and furthermore, echoing his praise for David Copperfield cited above, novels are superior in eliciting "efficient action in existing social controversy" (27).

Masson uses the association of the novel with the epic as a way to describe the general thematic territory of the genre, but he follows this discussion with an examination of the importance of a novel's conception: "In a prose romance or novel, as in a narrative or heroic poem, the first or main matter of interest for the critic, is the scheme, the idea, the total meaning, the aim, the impression, the subject" (31). Masson then succinctly sums up his conceptualization of belletristic propriety through a discussion of a novelist's duty to properly deploy realism, morality, and probability within a text:

[T]o state the matter differently, the novelist, as the creator of his mimic world, is also its providence; he makes the laws that govern it; he conducts the lines of events to their issue; he winds up all according to his judicial wisdom. It is possible, then, to see how far his laws of moral government are in accordance with those that rule the real course of things .... In short, the measure of the value of any work of fiction, ultimately and on the whole, is the worth of the speculation, the philosophy, on which it rests, and which has entered into the conception of it. (33)

Nowhere are Masson's belles lettres-inspired critical foundations more evident than in this examination of the interrelationship between a novel's realism and its moral structure. Masson's sense of novelistic propriety, founded on the twin concepts of realism and moral purpose, is exceptionally complex: novelistic realism is not simply located in a novel's mimicry of exterior reality, but is grounded in the conception of reality determined by the author to be appropriate to the novel's subject and purpose. Realism is not only an exterior criterion, but is also a matter of internal consistency; moral purpose is much more than a simple application of existing social mores to a narrative, but is also a measure of the novelist's ability to successfully execute the moral framework chosen for the novel (31-33). 
The centrality of propriety as a belles lettres-inflected critical criterion is clearly evident as Masson hones in on probability as a primary characteristic in the horizon of expectation for novels. Masson states that "improbability of an incident may well be its [a novel's] condemnation" and further, a reader's "resentment of improbability of incident is a wholesome critical feeling" (35). Probability, in fact, is Masson's dividing line between novel and romance. Romances typically contain incidents of lower probability than novels and thus "where we find a certain degree of ideality of incident, we call the work a Romance" (36). The belles lettres-influenced critical concern for moral content is once again present: Masson draws the line between good and great literature at the novelist's ability to "contrive ... to give us valuable matter over and above the mere fiction of the story" (41). Probability and virtue - foundational elements in the belles lettres rhetorical formulation of propriety are core concepts in Masson's novel theory.

After establishing the nature and centrality of propriety within his theory of the novel, Masson launches into a rapid-fire literary history of prose fiction, beginning in ancient times and concluding in the late seventeenth century. Masson's tour of prose fiction through the ages includes titles familiar to anyone interested in the history of the novel: Xenophon's Cyropaedia, Petronius Arbiter's Satyricon, the Golden Ass of Apuleius, and Longus' Daphnis and Chloe all make appearances as representatives of the ancient prose fiction canon. Masson moves along to include medieval prose fiction, such as The Lives of Barlaam and Josaphat by St. John Damascenus and the Thousand and One Nights. Medieval prose fiction also includes the countless saints' lives, Boccaccio's Decameron, and Arthurian romance, especially Malory's Le Morte d'Arthur. The list runs on through the Renaissance (Pantagruel, Astree, Amadis de Gaul, and Don Quixote) and into various permutations: chapbooks of fairy tales, picaresque stories, and utopian fiction (More's Utopia and Bacon's Atlantis) all make appearances before Masson concludes with extensive readings of Spenser's Faerie Queen, Sidney's Arcadia, and finally, Bunyan's Pilgrim's Progress. Masson pauses briefly, designates Aphra Behn as the most accomplished fiction-writer of the Restoration, and prepares to dive into the development of the English novel after 1700 (11-86).

The effect of this brisk recitation of well-known examples of prose fiction across centuries and cultures is somewhat dizzying, but Masson's point is clear: the English novel after 1700 is part of a long, respectable tradition of prose fiction that has existed since ancient times. Linking the novel to a respectable literary history is a belles lettres-inspired critical endeavor: belles lettres rhetoric emphasized the importance of studying approved models in the development of taste, and novels - even in mid-century Victorian England - were often seen as morally suspect. A respectable literary lineage could alleviate some of those concerns. Swift and Defoe (and Fielding, and Richardson, and the rest of the eighteenthcentury canon) could, at this point, all exist comfortably within a vast historical continuum of prose fiction.

Masson continues to weave rhetorical-historical concerns throughout his critical assessment of the novel in British Novelists. In his discussion of eighteenth-century British novels, Masson observes that fiction of the period is admirable not only for the realistic depictions of everyday life and firm moral purpose, but also for the stylistic excellence of the novels. Masson argues that in eighteenth-century novels, prose fiction - for the first time in literary history - exceeds poetry in conception of purpose and execution of design. Masson characterizes eighteenth-century poetry as mostly pedestrian, with the notable exceptions of Pope and Thomson. Eighteenth-century prose, though, is described as more consistently 
excellent, both in design and execution, than at any other time in the history of English literature:

It [the eighteenth century] is clearly an age in which Prose was, on the whole, the more congenial, and in which the most important and effective work of the British mind ... devolved on Prose naturally, and was shared in by Verse chiefly because Verse had come sorely down in the world. . . [H]as not Prose the evident advantage, even in the finer and subtler exercises of mind? (96)

The novel, in Masson's estimation, reached the height of belles lettres-inspired propriety in the eighteenth century as Defoe, Richardson, and Fielding fused realism, moral purpose, and excellence in narrative design and execution into a species of prose fiction which exceeded both contemporary poetry and almost all previous prose fiction in English.

Masson's belles lettres-informed critical tendencies extend to the final pages of British Novelists. As Masson summarizes the evidence of genius in novel writing, he invokes the concept most often identified with belles lettres rhetorical theory: the sublime. Masson reiterates that novels can - and sometimes do - rise to the same lofty heights as great poetry, despite the novel's typical concern with the commonplace and everyday: "It may be that the representation of social reality is, on the whole, the proper business of the Novel; but even in the representation of social reality the spirit may be that of the far-surveying and the sublime" (312). This evocation of the sublime as part of his closing statements on the novel serves as an emphatic coda to the belles lettres-inspired bases of Masson's critical project.

One conclusion about Masson's novel criticism presented in British Novelists that can certainly be reached is that the eighteenth-century belles lettres rhetorical theory to which Masson was intellectually indebted was a crucial component in his construction of a Victorian theory of the novel. Eighteenth-century belles lettres concerns for propriety, taste, and sublimity, expressed by Masson through explorations of style, taste, judgment, moral intent, probability, genius and the centrality of literary history, are diffused throughout the body of Masson's criticism, not only in his full-length scholarly texts like British Novelists, or in his periodical criticism, but also in his lectures delivered at the University of Edinburgh.

\section{Masson's Theory of Literature and Theory of the Novel: The University of Edinburgh Lectures}

WHILE MASSON'S PUBLIC CONTRIBUTIONS to Victorian novel criticism are relatively welldocumented, his academic work has received almost no attention. Masson's work in the academy deserves further scrutiny: for almost half a century, Masson taught rhetoric and English literature at University College London and the University of Edinburgh. Masson's role in the history of the novel within the academy is vital. Masson taught one of the earliest university courses in English literature and his lectures were immensely popular: during his tenure at the University of Edinburgh, his course in Rhetoric and English Literature averaged an enrollment of 183 students and over his twenty-four years at the University of Edinburgh, more than 4,000 students attended his lectures. ${ }^{13}$ Examining Masson's university lectures, in addition to his periodical criticism and full-length critical studies, clearly demonstrates his indebtedness to belles lettres rhetorical theory in the development and exposition of his own belles lettres-inflected critical stance regarding English literature, particularly fiction.

Before discussing Masson's work within the academy, it is important to examine the changing place of rhetoric and literature within the Victorian university. However, any attempt 
to understand the impact of rhetorical theory in the Victorian academy is confronted with a difficult fact: rhetoric, as a distinct and robust academic discipline, begins to disappear in the nineteenth century. As my description of the interwoven relationship of the belles lettresinfluenced critical tradition with its belles lettres rhetorical antecedents has demonstrated, rhetoric and criticism of the eighteenth century were closely related disciplines with oftblurred boundaries. As the nineteenth century progressed, though, the distinction between the two became increasingly pronounced. According to Hayden White, the disappearance of rhetoric during the nineteenth century is directly tied to the emergence of English literature as a specialized field of study within the academy. White describes this process as "the progressive derogation of rhetoric in favor of the elevation of poetic to the status of the very principle of literarity, on the one side, and its effective repression, in favor of promoting grammar and logic as the twin components of training in basic literacy, on the other" (25). White is arguing that rhetoric - as the study of the nature, function, and production of any mode of discourse - was displaced in the academy by a specialized veneration for "poetic" and artistic modes of discourse. The birth of literature as a distinct subject for academic study, according to White, sounded the death knell for a centuries-long tradition of intellectually robust rhetorical training and education.

White perhaps overstates the case: the nineteenth century was certainly not the first time that a revision to the purview of rhetoric had taken place, and arguments about the relationship among rhetoric, logic, and grammar have a permanent place in the history of rhetorical theory and pedagogy. But during the Victorian era, rhetoric is for the first time subsumed within another discipline. In White's formulation, rhetoric is suppressed by the elevation of literature within the academy. In actuality, rhetoric was not suppressed so much as conscripted by literary studies. Rhetoricians, critics, and literary scholars turned rhetoric's traditional emphasis on the production of discourse toward a focus on the analysis of discourse, and in the process, rhetoric's role in analyzing discourse became circumscribed within literary criticism.

The story of the transition from rhetoric to literary criticism, and the attendant development of English studies in the academy, has served as something of a counterhistorical account: as Robert Crawford observes, "the best-known accounts of the development of university English, such as those by Baldick, Eagleton and Graff, downplay or ignore eighteenth-century Scotland and assume that the middle or concluding years of the nineteenth century in England and America witnessed the subject's birth" (2). Yet, as Crawford and others argue, nothing could be further from the truth. As documented by Crawford, Winifred Bryan Horner, Thomas P. Miller, and other scholars, English studies developed out of the rhetoric courses of eighteenth-century Scottish universities and later in England at University College London and King's College as well as within the welter of mechanics' institutes, dissenting academies, trade schools, and informal improvement societies which emerged during the eighteenth and nineteenth centuries.

One reason that the development of English as a field of study within university rhetoric courses is a less familiar component in disciplinary histories is because, as Horner tells us, "nineteenth-century Scottish rhetoricians . . . usually did not publish their lectures, and, as a result, we are largely ignorant of their important influence" ("Nineteenth-Century Rhetoric" 365). Yet, as Horner demonstrates in Nineteenth-Century Scottish Rhetoric: The American Connection, it is possible to develop a clear understanding of what was taught in nineteenthcentury English literature courses in the Scottish universities. Horner's archival work at the 
four ancient Scottish universities reveals the presence of English literature as course material in Scottish universities throughout the nineteenth century.

Horner's excellent annotations to her archival work reveal belles lettres-inflected critical underpinnings of these new courses in English literature. At the University of Glasgow, Horner highlights the work of John Nichol, the university's first professor of English literature. ${ }^{14}$ In his inaugural lecture at the University of Glasgow in 1862, Nichol's concern for the improving nature of literature demonstrates a clear debt to belles lettres-influenced critical principles:

\footnotetext{
The study of our own literature encourages the best sort of patriotism, our pride in our great men. It enlarges our ideas by enabling us to penetrate into their minds and stimulates us to emulate, by setting forth, the qualities which made them great. It takes away our jealousies, by holding up standards, in following which we have need to resign our self-complacency, and waive a little of our individual claims. It tones our rancour down, by showing us the common grounds on which we may meet and shake hands. The study of works which time has allowed to last, is, above all, the best corrective to the impatience of an age ... more noted for critical acuteness than magnanimity (qtd. in Horner, Nineteenth-Century 127)
}

As Horner observes, Nichol's views are "traditional" in the sense that he espouses a typical mid-century attitude concerning the importance and place of literature studies (108). These traditional views, though, are belles lettres-inspired in their foundation: references to "great men" and "standards" and "works which time has allowed to last" all echo a concern for approved models, fixed notions of taste, and the importance of literary history in the development of correct taste and judgment developed within eighteenth-century belles lettres rhetoric.

These observations about the general nature of nineteenth-century literature studies at Scottish universities, though, do not necessarily answer any questions about the place of the novel in Scottish university literature courses. ${ }^{15}$ But the novel was present in the Scottish universities, and as Paul Bator argues, the novel found its way into university curriculum precisely because of the belles lettres rhetorical movement within the eighteenth-century Scottish university (89-91). Bator asserts that the novel was addressed within the belles lettres rhetorical theories of Adam Smith and Hugh Blair because "the Scottish professors of Rhetoric and Belles Lettres began to view the novel as a utilitarian work of prose fiction that could serve their need for instructive moral examples of taste, sympathy and discreet as well as indiscreet character" (91). Novels, in other words, could be used as a testing ground for evolving belles lettres rhetorical principles. Bator continues, asserting that as belles lettres rhetorical theory shifted emphasis away from the production of texts and toward the analysis of texts, the prevalence of belles lettres rhetoric in the Scottish universities provided "an institutional avenue for the reading and critical consumption of the novel" (92). As many other scholars have demonstrated, there was a great deal of anxiety in the eighteenth century about which novels were suitable for study. The result of this anxiety, Bator observes, was a concerted effort on the part of Scottish librarians and rhetoric professors to sanction only "first-tier" fiction (91).

Bator's scrupulous research demonstrates the presence of the novel in the eighteenthcentury Scottish university rhetoric courses: in Smith's lectures at the University of Glasgow, in Blair's lectures at the University of Edinburgh, in James Beattie's lectures at the University 
of Aberdeen, and in William Barron's lectures at St. Andrews (92-94). But as Bator observes, these lectures do not treat the novel at any great length and typically end with a warning that readers - particularly young and inexperienced readers - should be very careful about the quality and quantity of novels they consume $(91,93)$. Furthermore, Bator warns that it should not be inferred that novels were being "taught" in these courses:

\begin{abstract}
Since hard curricular evidence or data such as reading lists, syllabi, or detailed assignments is difficult to come by, it should not be said that the novel was actually being 'taught' per se in the Scottish universities of the eighteenth century as there was no organized method of introducing novels or novelists; furthermore, the novel was a mixed form of prose fiction and not yet a pure genre by any means. (92)
\end{abstract}

Sidestepping any questions about what a "pure genre" might be, Bator's work shows that the novel was considered worthy of academic attention in the Scottish universities at least as early as Smith's lectures in the 1750s. Yet a complete treatment of the novel as a fully accepted genre within the academy was not to come until the nineteenth century.

In the nineteenth century, the most high profile figure to promote, theorize, and teach the novel in a university setting was David Masson. The substance of Masson's lectures is preserved in seven sets of course lecture notes taken down by students (including Peter Pan author, James M. Barrie) and housed at the University of Edinburgh and the National Library of Scotland. Masson never formalized his lectures for publication: the available lecture notes cover seven different terms across twenty years, the earliest from 1868 and the latest from 1889. While there are variations between the different versions of the lecture notes (for example, none of the lecture notes give the same title for Masson's course), the lectures demonstrate a remarkable level of uniformity, despite seven different note-takers across two decades.

Along with these manuscript student notes of Masson's courses housed in the University of Edinburgh archives is an extant copy of Masson's inaugural lecture after his appointment to the Regius Chair of Rhetoric and English Literature in 1865, published with limited notes in Studies in Scottish Literature in 1979, as well as a pamphlet version of Masson's opening lecture of the 1866-67 term, titled The State of Learning in Scotland. The text of Masson's inaugural lecture serves as a useful précis for his entire tenure at the University of Edinburgh. In the inaugural lecture, Masson outlines two major concerns of the course: the nature of literature, and the purpose of rhetoric in relationship to literature.

As for the first concern, Masson's initial definition of literature is exceptionally broad. Literature, Masson tells us, is all-encompassing:

[Literature is] all the manuscripts or scraps of writing, all the printed pages or flyleaves or books, all the monumental records, all the inscriptions on tombstones, even, preserving thoughts, or statements, or feelings, or tissues of such, that have emanated from individual minds or from minds collectively, from the beginning of human society - all such things belong to the inventory of the world's literature, if it were to be itemed to its absolute totality. ("Inaugural" 240)

Such a range is obviously beyond the scope of a single course in rhetoric and English literature, and so Masson provides some limits to his future subject matter. For this task, Masson turns to De Quincey, and his notion of literature of knowledge and literature of 
power. De Quincey's delineation between texts that simply provide information and texts that seek to move the reader in some fashion is well known. For Masson, this is the crucial dividing line between literature in general, and his concept of literature as a fine art. He argues that limiting the study of literature to the study of De Quincey's notion of "literature of power" allows for the possibility of a systematic approach to literary theory (242). He then divides literature into four classes: Historical Literature, or Literature of Memory; Didactic Literature, or Literature of Exposition or Reason; Poesy, or Literature of the Imagination; and finally, Persuasive, or Oratorical Literature. Masson cautions that such divisions might provide a useful heuristic, but that, in practice, such rigid distinctions cannot be maintained (242-43).

After defining literature, Masson proceeds to describe the relationship between literature and rhetoric. This relationship is clearly belletristic in its primary expression: Masson declares that the critical project of any study of literature is the study of style, with attention to perspicuity, taste, and artistic beauty (243-44). In a clear echo of Blair's statement of purpose for the Lectures in Rhetoric and Belles Lettres, Masson asserts that there are two methods for developing a critical understanding of literary style: first, "through the study of actual examples of the highest excellence ... or, by an analysis, having for its end, the discovery of the means whereby, according to the constitution of the human mind, this or that mental effect may be produced" (244). The nature of Masson's course is exceptionally clear: through an examination of widely accepted examples of great literature throughout literary history, belles lettres-informed critical principles of propriety, taste, and sublimity can be examined, extracted, understood, and applied to the analysis of any text.

The emphasis on rhetorical theory and literary history laid out in the inaugural lecture is immediately evident in the student notes, beginning with the earliest existing copies of Masson's lecture notes, taken during the 1868-69 term. Here, Masson describes rhetoric as "the science of literature" (4) and Masson's description of how to perform literary criticism reads like an application of stasis theory to literary works (Notes of English Literature 120 $31) .{ }^{16}$ The notes from the 1870-71 term include a useful précis which outlines the structure of Masson's lectures: the first half of the course focuses on rhetoric and criticism, especially tropes, figures of speech, and style; the second half of the course provides a history of English literature, classifications of literature, and some application of the rhetorical criticism from the first part of the course (Notes on Prof. Masson's Lectures). In the lecture notes taken by Barrie during the 1881-82 term, Masson clearly indicates that rhetorical theory is central to literary criticism: Masson's third and fourth lectures deal with tropes and figures at great length, and he cites several eighteenth- and nineteenth-century rhetoricians (including Kames, Campbell, Blair, Whately, and Bain) as authorities on style, a central focus in Masson's development of a belles lettres-derived critical structure (Rhetoric I \& English Literature). Despite the systematic approach to rhetoric in the service of literary criticism, Masson explicitly rejects the notion that criticism can be performed through rote responses to rhetorical conventions. Masson reminds his students that rhetorical theory should not mechanize their approach to criticism, stating that "[1]ike all sound theory, it [rhetorical methodology] helps to guide and correct practice" and furthermore, "No able critic would think of making any mechanical apparatus [to render judgments]" (Rhetoric I \& English Literature).

Yet for the most part, Masson's approach to literary criticism is driven by a sense of history: as he states in the opening lecture of the 1866-67 term, "all learning resolves itself into history" (State of Learning 22). Throughout the lecture notes, Masson devotes a large 
number of lectures to developing a notion of the historical periods of English literature (in the lecture notes, Masson seems to delineate five or sometimes six historical periods, though the variation may be the fault of the various note-takers). Prose fiction - whether under the guise of romance or novel - is mentioned as early as 1688 and is typically divided into two historical periods: pre-1789 and post-1789. The nature of the lecture notes makes it difficult to ascertain exactly how Masson is treating the novels. Several of the sets of lecture notes seem to indicate that Masson had little to say regarding theory or criticism of the novel, and simply listed the authors (and sometimes the works) associated with each period. Even these lists, though, are instructive. Masson's informal canon is clearly influenced by the novel histories and canons of the romantic era. ${ }^{17}$ Taking all the lecture notes together, Masson's canon is quite familiar: he includes Defoe, Swift, Richardson, Fielding, Smollett, Johnson, Walpole, Goldsmith, MacKenzie, More, Inchbald, Burney, Austen, Godwin, Beckford, Radcliffe, Scott, Edgeworth, Lytton, Dickens, Thackeray, Eliot, the Brontë sisters, and nominates Dickens and Thackeray as the best contemporary novelists. In the notes from the 1881-82 term taken by George J. Lumsden, Masson claims that there are twenty different varieties of novels, but Lumsden includes no taxonomy of novel types (Rhetoric and English Literature).

But in other copies of the lecture notes, Masson makes critical judgments about novels. ${ }^{18}$ In a set of anonymously recorded notes from the 1878-79 term, Masson names Richardson the "Father of the modern English novel" and praises Defoe's novels as "facsimiles of the real" (Lectures on English Literature). Masson also states that "at the end of the previous period [of his divisions of English literary history], the novel of society was an established literature . . . cultivated chiefly by ladies" and of these society novels, "Austen is the chief novelist of the time." 19 The notes taken by Lumsden during the 1881-82 term include similar information about the English novel: Radcliffe, Edgeworth, and Austen are named the leading novelists at the turn of the previous century. At this point, Masson reiterates a point about the place of women in the history of the novel that he first offered in British Novelists, claiming that the novel has become a literary fortress long garrisoned by women, and that no male novelists of the romantic era, save Godwin, had achieved the same level of artistic success as their female counterparts (179). In the lecture notes, this idea is truncated, but the presence of Masson's public criticism in his academic work is unmistakable.

\section{A Conclusion: David Masson's Victorian Theory of the Novel}

THROUGHOUT HIS CRITICISM - in the periodical press, in his full-length British Novelists, and in his university lectures - Masson develops one of the most extensive and fully-realized iterations of novel theory to emerge during the Victorian era. Masson's theory of the novel is a thorough, meticulous, and systematic examination of the genre as it was understood in the latter half of the nineteenth century. While Masson's belles lettres-informed critical approach is clearly indebted to a belles lettres rhetorical foundation from the previous century, it is also consciously situated within the cultural and aesthetic concerns of latter nineteenth-century Victorian England. Specifically, Masson frames his theory of the novel within a reading of rhetorical theory and literary history which focuses on a particularly belles lettres-influenced triumvirate of propriety, taste, and sublimity (the last often in conjunction with genius) as the key defining characteristics of the genre.

While it is probably going too far to characterize Masson's work as the Victorian theory of the novel, it is hard to avoid seeing his work as an immensely influential expression of 
a Victorian theory of the novel. Masson's theorization of the novel was echoed by other critics, essayists, publishers, and non-academics, and if he was not solely responsible for a belles lettres-infused approach to novel criticism in the Victorian era, his vast influence - as an editor, essayist, and academic - certainly helped sustain the belles lettres-inspired critical tradition throughout the latter half of the nineteenth century. The persistence of belles lettres-inflected critical concepts in Victorian assessments of the novel manifested itself in virtually every nook and cranny of Victorian literary culture, though perhaps a brief examination of just one obscure example will prove instructive. In 1870, William P. Nimmo, an Edinburgh editor, produced Episodes of Fiction, a Ballantyne and Company gift edition of selections from a standard canon of British fiction. In the introduction, the volume's purpose is stated in Masson-esque language: Nimmo claims that the selections were chosen "with the view of illustrating the general character of their style, and presenting the reader with an opportunity of comparing the present school of fiction with the past" (vii-viii). Nimmo's brief introductory statement encapsulates Masson's articulate, extensive, and systematic approach to a theory of the novel: the belles lettres-inspired concern for propriety of style is fused with the need for a correct perspective on literary history. The invocation of style and the implicit necessity for correctly formed taste in order to render proper judgment when comparing present examples with past standards are central concepts in Masson's theory of the novel, a theory which influenced generations of periodical readers and university students from London to Edinburgh, and far beyond.

Washington State University - Spokane

\section{NOTES}

1. In 1762, Blair was named the university's first appointee to the Regius Chair of Rhetoric and Belles Lettres. The University of Edinburgh cites this date (1762) as the foundation of their department of English; thus 2012 was celebrated as the 250th anniversary of English studies at Edinburgh.

2. St. Clair also argues that Blair's Sermons, first published in 1778, are the most useful text for identifying an "official ideology" during the romantic period (270). The Sermons were "officially recommended as a source from which all those in authority could safely draw in giving their own advice" (270), and the archival records show that almost a quarter of a million copies of Blair's Sermons were sold by 1815 (271).

3. Of the English professors listed by Ferreira-Buckley, only Alexander Blair and David Masson are Scottish. Other significant nineteenth-century Scottish born and educated professors who taught English literature in the Scottish universities include William Spalding (University of Edinburgh, 184045), William Edmondstoune Aytoun (University of Edinburgh, 1845-65), John Nichol (University of Glasgow, 1862-89), Alexander Bain (University of Aberdeen, 1860-80), and Herbert J. C. Grierson (University of Aberdeen, 1894-15) (Horner, Nineteenth-Century Scottish Rhetoric 54164).

4. See Ferreira-Buckley, 184-95.

5. Adam Smith lectured on rhetoric and belles lettres (among other subjects) at the University of Edinburgh from 1748-51 and later at the University of Glasgow from 1751-63. These lectures were never published during his lifetime and are known only through a single set of student lecture notes taken during the 1762-63 term, and were published for the first time in 1963. Other influential treatments 
of belles lettres theory by eighteenth-century Scottish intellectuals might include Henry Home, Lord Kames's Elements of Criticism (1762), George Campbell's Philosophy of Rhetoric (1776) and James Beattie's Dissertations Moral and Critical (1783).

6. Masson kept meticulous records of the students enrolled in his courses. According to Masson's records, his students hailed from across the globe: Jamaica, Australia, the United States, South Africa, Poland, Canada, Ireland, Wales, India, and of course, Scotland. Masson's students most likely comprised a mixture of low-to-upper middle class students from non-Anglican backgrounds from around the English-speaking world. His course lists include students as young as fifteen and as old as thirty-six. Despite Masson's aggressive attempts to bring about the admission of women to the University of Edinburgh, all of his students were men.

7. Masson's Dictionary of Literary Biography entry asserts that due to his reputation and corpus, "Masson occupies a rank only slightly below that of the greatest Victorians." In British Authors of the Nineteenth-Century, Kunitz and Haycraft attest to Masson's importance as a standard authority on Milton, Goldsmith, and De Quincey and characterize him as "a writer of good judgment and sound sense."

8. Masson's Milton biography was considered to be one of the foundational texts in Milton studies well into the twentieth century.

9. Blair's Lectures were published in 1783, but Blair began lecturing on rhetoric as early as 1759 . An examination of his existing lecture manuscripts from 1765 and 1779, compared to the vast number of editions published after 1783, show that the substance of the lectures and their approach to the relationship between rhetoric and belles lettres changed very little over the course of Blair's career at the University of Edinburgh. I have examined editions of the Lectures from 1783 and 1790, but all citations are drawn from the 1785 second edition, edited by Ferreira-Buckley and Halloran.

10. Masson does not ignore sublimity in his critical work or academic lectures; rather, sublimity is subordinated within a Romantic-infused notion that genius is often characterized by a writer's ability to successfully and consistently achieve the sublime in her or his writing.

11. I attempted Masson's challenge to identify the authors simply through a reading of style, and though it has been some time since I last read Copperfield or Pendennis, I managed to identify the Copperfield passage through just one stylistic observation: Dickens's penchant for absurd names. In the passage presented, the reader meets Creakle and Traddles, names that are clear calling cards of Dickens's style.

12. Masson makes it clear that he believes such a preference for Anglo-Saxon linguistic purity within the English language is useless and unnecessary.

13. See University of Edinburgh Enrollment Book. Prior to Masson's appointment, William Edmondstoune Aytoun's course averaged eighty-three students over twenty years, though to be fair, the enrollments in Aytoun's courses represented a significant increase versus the enrollments of his immediate predecessor, William Spalding. Masson's popularity with his students is evidenced in the various newspaper clippings that announce Masson's public lectures and are slipped into the student lecture notes housed at the University of Edinburgh.

14. Nichol served as the Regius Professor of English Language and Literature at the University of Glasgow from 1862-89 (Kunitz and Haycraft 471).

15. Horner makes tantalizing reference to nineteenth-century Aberdeen University literature professor Herbert J. C. Grierson's lecture notes, saying that one copy of notes housed at the university contains "a section on the novel" (Nineteenth-Century 164).

16. Stasis theory is an ancient rhetorical concept in which the speaker (or writer) determines the nature of an argument (typically in a legal setting) by asking a series of questions and evaluating the responses. Stasis theory, as developed by Hermagorus, involves four lines of questioning: 1. Conjecture (Did something occur?) 2. Definition (What sort of thing was done?) 3. Qualitative (Was the deed legal?) 4. Translative (Is this the correct venue for trying the case?) (Lanham 93-94). Masson suggests asking the following series of question when approaching a literary text: 1 . Is the author a poet? 2 . What is 
his worth as a poet? 3. In what kinds of circumstances does he excel as a poet? 4. In what emotional key is his poetry? 5. In what proportion is his [work] poetic?

17. Especially as described by James Beattie in Dissertations Moral and Critical (1783), Clara Reeve in The Progress of Romance (1785), Anna Laetitia Barbauld in On the Origin and Progress of NovelWriting (1810), and Walter Scott in Notices Biographical and Critical (1820).

18. One amusing moment of what might be Scottish pride occurs when Masson declares that Shakespeare was the Sir Walter Scott of his era (Notes of English Literature).

19. At this point in the lecture notes, the note-taker inscrutably notes Masson's assertion concerning novel publishing data, claiming that in 1820, twenty-six novels were published; only ten years later, in 1830, Masson claims that over one hundred were published. Masson's assertions seem generally accurate when compared to the data for nineteenth-century British novel publication examined in Moretti's Graphs, Maps, and Trees. Moretti's data indicates the publication of some fifty or sixty new novels in 1820; by 1830, though, the number seems to have risen to more than one hundred new novels published in Great Britain (7).

\section{WORKS CITED}

Aytoun, William Edmondstoune. University of Edinburgh Enrollment Book. 1845-65. MS Da 35 RHE 1. University of Edinburgh Library, Edinburgh.

Bator, Paul G. "The Entrance of the Novel into the Scottish Universities." The Scottish Invention of English Literature. Ed. Robert Crawford. Cambridge: Cambridge UP, 1998.

Bizzell, Patricia, and Bruce Herzberg. The Rhetorical Tradition: Readings from Classical Times to the Present. Boston: Bedford/Saint Martin's, 2001.

Blair, Hugh. Lectures on Rhetoric and Belles Lettres. 1783. Ed. Linda Ferreira-Buckley and S. Michael Halloran. Carbondale: Southern Illinois UP, 2005.

- Lectures on Rhetoric and Belles Lettres (manuscript lecture notes written by Blair). 1765. Dc 10.6. University of Edinburgh Library, Edinburgh.

- Lectures on Rhetoric and Belles Lettres (manuscript lecture notes written by Blair). 1779. Gen 1990. University of Edinburgh Library, Edinburgh.

- Lectures on Rhetoric and Belles Lettres. 1790. PE 1402.B6. Gonzaga University, Foley Center Library Special Collections, Spokane, WA.

Crawford, Robert, ed. The Scottish Invention of English Literature. Cambridge: Cambridge UP, 1998.

Eigner, Edwin M., and George J. Worth. Victorian Criticism of the Novel. Cambridge: Cambridge UP, 1985.

Engell, James. "The New Rhetoric and Romantic Poets." Rhetorical Traditions and British Romantic Literature. Ed. Don H. Bialostosky and Lawrence D. Needham. Indianapolis: Indiana UP, 1995.

Ferreira-Buckley, Linda. "Scottish Rhetoric and the formation of literary studies in nineteenth-century England." The Scottish Invention of English Literature. Ed. Robert Crawford. Cambridge: Cambridge UP, 1998.

Gore, Catherine. "The Dowager; or, the New School for Scandal." The Athenaeum (14 Nov. 1840): 899-900.

Horner, Winifred Bryan. "Nineteenth-Century Rhetoric at the University of Edinburgh with an Annotated Bibliography of Archival Materials." Rhetoric Society Quarterly 19.4 (Autumn, 1989): 365-75.

- Nineteenth-Century Scottish Rhetoric: The American Connection. Carbondale: Southern Illinois UP, 1993.

Kunitz, Stanley, and Howard Haycraft. British Authors of the Nineteenth Century. New York: H. W. Wilson, 1936.

Lanham, Richard A. A Handlist of Rhetorical Terms. 2nd ed. Berkeley: U of California P, 1991.

Masson, David. "Book Review [A Man Made of Money]." The British Quarterly Review 10.19 (1849): 192-208. British Periodicals. Web. 8 Oct. 2012. 
- "ART. III.-1. the Personal History and Experience of David Copperfield the Younger." The North

British Review 15.29 (1851): 57-89. British Periodicals. Web. 8 Oct. 2012.

. British Novelists and their Styles. London: MacMillan, 1859.

. "Inaugural Lecture." 1865. Studies in Scottish Literature 14 (1979): 240-49.

. University of Edinburgh Enrollment Book. 1865-1889. MS Da 35 RHE 2. University of Edinburgh

Library, Edinburgh.

- The State of Learning in Scotland. 1866. L 11.A v. 12 c. 1. Johns Hopkins University, Milton S.

Eisenhower Library Special Collections, Baltimore.

- Notes of English Literature: From Lectures on Rhetoric and English Literature by Prof. Masson. 1868-1869. MS Gen. 1401-1403. University of Edinburgh Library, Edinburgh.

- Notes on Professor Masson's Lectures. 1879-1880. Dk. 1.3/2/2. D 6321. University of Edinburgh Library, Edinburgh.

- Wordsworth, Shelley, Keats, and Other Essays. London: Macmillan's, 1874.

. Lectures on English Literature. 1878-1879. Gen. 2076. University of Edinburgh Library, Edinburgh.

. Rhetoric I \& English Literature. 1881-1882. MS 6652. National Library of Scotland, Edinburgh.

. Rhetoric and English Literature. 1881-1882. MS DK 4.28 - 31. University of Edinburgh Library, Edinburgh.

Miller, Thomas P. The Formation of College English. Pittsburgh: U of Pittsburgh P, 1997.

Moretti, Franco. Graphs, Maps, and Trees: Abstract Models for Literary History. New York: Verso, 2007.

Nimmo, W. P. ed. Episodes of Fiction. Edinburgh: Balantyne, 1871.

Olmsted, John C. A Victorian Art of Fiction: Essays on the Novel in British Periodicals, 1830-1850. New York: Garland, 1979.

Rhodes, Neil. "From Rhetoric to Criticism." The Scottish Invention of English Literature. Ed. Robert Crawford. Cambridge: Cambridge UP, 1998.

Shattuck, Joanne. "Professional Networking, Masculine and Feminine." Victorian Periodicals Review 44.2 (Summer 2011): 128-40.

St. Clair, William. The Reading Nation in the Romantic Period. Cambridge: Cambridge UP, 2004.

White, Hayden. "The Suppression of Rhetoric in the Nineteenth Century." The Rhetoric Canon. Ed. Brenda Deen Schildgen. Detroit: Wayne State UP, 1997. 21-31.

Wilson, Hugh. "David Masson." Nineteenth-Century British Literary Biographers. Ed. Steven Serafin. Dictionary of Literary Biography Vol. 144. Detroit: Gale Research, 1994. Literature Resource Center. Gale. Northwest University Library. Web. 4 Feb. 2011

Warnick, Barbara. The Sixth Canon: Belletristic Rhetorical Theory and Its French Antecedents. Columbia: South Carolina UP, 1993. 